\title{
Gentrification and Touristification in the Central Urban Areas of Seville and Cádiz
}

\author{
Julio-José Parralejo ${ }^{1, *(D)}$ and Ibán Díaz-Parra ${ }^{2}$ \\ 1 School of Geography, University of Seville, 41004 Seville, Spain \\ 2 Department of Human Geography, Faculty of Geography and History, Rectorate Campus, \\ University of Seville, 41004 Seville, Spain; ibandiaz@us.es \\ * Correspondence: juliojparralejo@gmail.com
}

check for updates

Citation: Parralejo, J.-J.; Díaz-Parra, I. Gentrification and Touristification in the Central Urban Areas of Seville and Cádiz. Urban Sci. 2021, 5, 40. https://doi.org/10.3390/ urbansci5020040

Academic Editors: Deborah Edwards and Frank Witlox

Received: 15 February 2021

Accepted: 29 April 2021

Published: 2 May 2021

Publisher's Note: MDPI stays neutral with regard to jurisdictional claims in published maps and institutional affiliations.

Copyright: (c) 2021 by the authors. Licensee MDPI, Basel, Switzerland. This article is an open access article distributed under the terms and conditions of the Creative Commons Attribution (CC BY) license (https:// creativecommons.org/licenses/by/ $4.0 /)$.

\begin{abstract}
Intensive tourism in historic city centers is causing socio-spatial effects that are already visible to society. This has led politicians and academics to focus on the issue, creating a debate about gentrification in certain central urban areas which overlaps with studies on touristification, understood by some authors as tourism gentrification. This article aims to identify whether sociodemographic changes identifiable as touristification have occurred in the historic centers of two Andalusian cities, Seville and Cádiz, and which we interpret as the replacement of residents with visitors. The work is based primarily on the exploratory analysis of socio-demographic data from the Population Register and data on housing and rentals provided by different sources. The work shows strong indications of a relationship between the increase of tourist apartments and losses of residents in both historic centers. The paper concludes by pointing to the need for further research on this relationship in public statistics that can guide future policy action.
\end{abstract}

Keywords: gentrification; touristification; tourist housing; Airbnb; historic center; population

\section{Introduction}

In recent years, there has been increasing concern about the impact of intensive tourism, both politically and academically. This has been especially noticeable in southern European cities such as Athens, Barcelona, Lisbon, and Rome, among others. Ref [1] Spain's status as a tourist power has increased the prominence of this type of process.

Ref [2] This type of impact has attracted the attention of the World Tourism Organization and the European Parliament. Although concern about the impact of tourism is not new, the recent focus is in response to an intensification of tourist flows and the expansion of tourism processes into new areas. There may be several reasons for this. For relatively poor regions, tourism has become the main way of attracting economic resources [3]. Furthermore, in recent years, the role of certain innovations in the tourism sector has developed or strengthened with a significant impact, such as low-cost airlines, cruise tourism, and the more recent emergence of online platforms that offer tourist accommodation $[4,5]$

In this way, tourism has become the main source of income for many cities in the country, leading to the professionalization of the sector and the increasing use of new technologies [6] that can offer high quality services and enable access from different social classes, in addition to the strong internationalization that has been growing in recent years. Since the economic crisis of 2008, tourism has gained even more prominence in job creation and in its share of the GDP [7]. This has coincided with some social alarm about the saturation of visitors in certain cities, especially in historic centers, with particular attention to the growth of tourist apartments [8,9]. The impact of temporary tourist rentals and Airbnb-type platforms has changed consumption patterns in the tourist accommodation sector [10]; while multiplying the possibilities for tourists to visit cities and access a wide range of experiences, it has been able to boost the number of tourists, both in traditionally touristy and non-touristy cities, leading to some congestion and competition for space with 
conventional rentals in the most visited historic areas. This brings up the issue of the need for state regulation of these activities [11].

The term touristification, which can be defined as the ongoing transformation of urban environments from tourism and tourists, has become especially popular in Spanish academia in the last five years and is closely linked to the studies on gentrification in the central areas of large cities that were starting to be developed a decade ago. This narrative mostly originated from the idea of tourism gentrification, which was first introduced by Gotham [12] and has since been followed up by many researchers [13,14].

Questioning the appropriateness of talking about tourism gentrification, Jover and Díaz-Parra [15] argue for the need to differentiate traditional residential gentrification and touristification, given that, despite responding to similar mechanisms, these two processes would have different demographic effects. According to Clark [16], gentrification refers to the phenomenon of the substitution of residents and users of a certain urban sector for others who have greater purchasing power, mediated by investment in the built environment of the traditional population of a neighborhood. This element would respond to the classic conceptualization of Smith [17], who explained gentrification as a consequence of the reinvestment of real estate capital in previously devalued areasthe main driver of this transformation being the benefit derived from the increase in land rents, which is called the rent gap. The notion of transnational gentrification, by contrast, can be interpreted as the process of new residents with higher status coming from other countries. Touristification, on the other hand, could be seen as a substitution for tourists and occasional visitors rather than for new households of a higher social class than the pre-existing ones [18]. Jover and Díaz-Parra [15] highlight this difference, insofar as touristification, unlike gentrification, should lead to some depopulation (in relation to established residents). Other authors point to the lack of evidence on the relationship between tourist rentals and population displacement [19]. In turn, ref [20] speak of a tourist rent gap that would place the driving force of the process in the existing difference between conventional rentals and tourist rentals.

This work is part of a broader doctoral study on the processes of gentrification and touristification in the Andalusian cities of Cádiz and Seville. The first part of the project is mainly focused on the exploratory and descriptive analysis of the impact of the intensification of tourist uses on housing, and the structure and socio-demographic evolution of the central areas of these cities.

Figure 1 shows where the historic centers of Seville and Cádiz are located within their municipalities. 


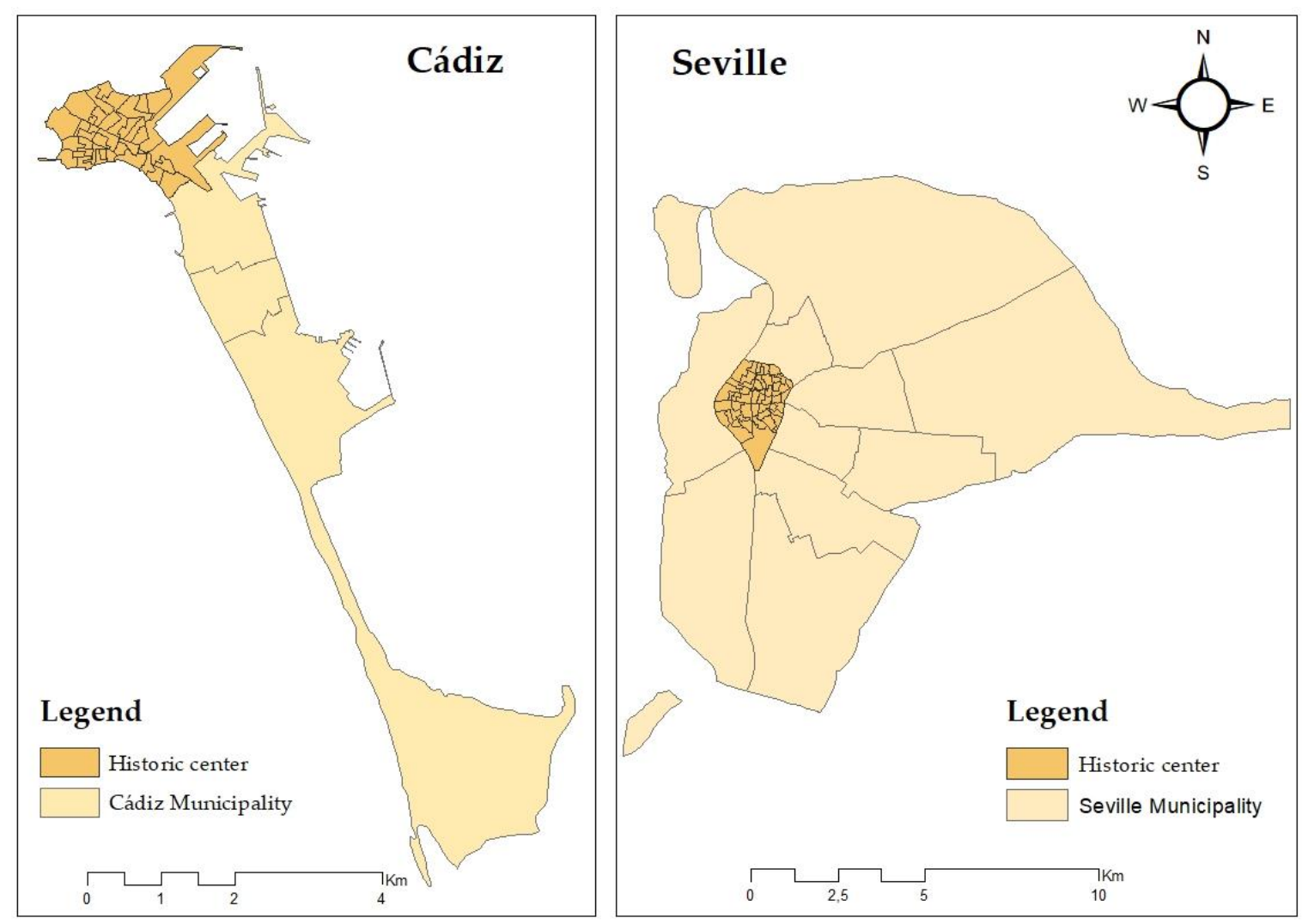

Figure 1. Historic centers of Seville and Cádiz. Source: Prepared by the authors with data from the IECA [21].

The cases of Seville and Cádiz are of considerable interest. Both are tourist cities with large historic centers that have become important economic resources for the local economy, with a recognized history and evolution in recent decades. By studying Seville (an inland city) and Cádiz (a coastal city), the study can be extrapolated to other cities with similarities to Seville and Cádiz. Seville, with around 690,000 residents [22], is the Andalusian city with the highest number of tourist dwellings and the second city in Spain, after Madrid. It has the largest proportion of residential dwellings dedicated to tourist use in its historic center and receives almost 3 million visitors a year. On the other hand, Cádiz, with more than 116,000 residents [22], occupies a more secondary position with respect to the number of tourist apartments, but it is the city where cruise tourism has grown the most in recent years, outside the island territories, reaching more than 260,000 visitors.

After this short introduction, which includes a brief state of affairs, the work includes a methodological section which describes the steps followed in the analysis, sources used, and justification of the different indicators. The results are presented below, where we comparatively and consecutively explore, firstly, the data on tourist dwellings and housing uses and, secondly, the socio-demographic evolution of the population. The article ends with a brief conclusion section.

\section{Methodology}

An exploratory comparative analysis will be carried out between the two cities. This analysis is divided into two distinct parts. The first part focuses on data on housing and tourist rentals. The second part analyses the socio-demographic changes in these cities. The study area is defined by the municipal districts of both cities and, within these, the historic centers, defined by their walled enclosure. The study period covers the development of these cities during the 21st century, starting in 2001, the date of the penultimate population and housing census, and ending in 2018, the date on which the latest census data was published by the Andalusian Institute of Statistics and Cartography. The temporality of 
the data varies according to the source. It is possible to obtain the demographic data for each year between 2001 and 2018, while the housing data are mostly provided only synchronously for 2018.

The analysis of demographic statistics is based on the hypothesis that the increase in tourist apartments, as a result of the impact of platforms such as Airbnb [23], could put a brake on the trend of the last two decades in Andalusian historic centers. This could lead to a reversal, or at least a halt to the demographic decline they have been experiencing since the second half of the 20th century. These previous gains would be the result of a process of gentrification, so touristification and gentrification would have contradictory effects on this type of space.

The study of housing draws on a variety of sources. Firstly, we use the information provided by the population and housing census, which has the known limitation of its periodicity, so we only have data from 2001 and 2010. However, it does offer some interesting information on the use of housing. The data on tourist dwellings are based on the compilation of data on the Datahippo platform [24]. At present, Datahippo does not provide time series, so only stock data are available. The impact of online platforms that allow the transformation of dwellings into tourist apartments (Airbnb, Homeaway, etc.) is limited to the last five years and the official registers only started to operate a couple of years ago, when it became mandatory to declare dwellings for tourist purposes [25]. For the impact of tourist rentals operating via digital platforms, the reference date is 2012, the year in which Airbnb went international and opened its first office in Spain (Barcelona).

The difference between conventional and tourist rentals, understood as a proxy for the aforementioned tourist rent gap [20], has been taken as an explanatory variable. The data on conventional rentals have been extracted from the website Idealista.com [26]; the data on tourist rentals were taken directly from the Airbnb platform. Both were used to identify the average prices of tourist rentals in the historic centers of these cities. The obstacle to the tourist rental price data is the extreme variability of rental prices throughout the year. This has been partially overcome by obtaining the data for different periods of the year (high season and low season). For this, it has been necessary to make two assumptions in order to compare the two types of rentals. First, it has been assumed that there are three months of the high season and nine months of the low season. In the high season, Seville can exceed 500,000 overnight stays and Cádiz 67,000 according to data from the Hotel Occupancy Survey (EOH) [27] of the National Statistics Institute (INE 2018). The specific high season data for both cities have been obtained from two festivals declared of International Tourist Interest, which is an honorary distinction granted in Spain by the General Secretariat of Tourism of the Ministry of Industry, Tourism, and Trade. The festival in Seville is the traditional Easter festival, with more than $90 \%$ hotel occupancy according to the Seville and Province Hotel Association [28]. On the other hand, the festival in Cádiz is the famous Carnival, celebrated in the city where hotel occupancy reaches $95 \%$ according to the Federation of Hotel Businessmen of the Province of Cádiz [29]. The other assumption is that the tourist dwelling would be rented for the whole month in the three months of high season and half of the month in the nine months of low season.

In view of the lack of data on the size of tourist rentals, the rentals in two-bedroom dwellings were compared. The differences for the types of housing and different times of the year are used to extract an average, an indicator that would roughly reflect the difference in profits between conventional and tourist rentals as a driver of touristification. It should be borne in mind that it is intended to approximate the benefit of renting a property, although real estate, administrative, or fiscal costs should also be taken into account to obtain a more realistic figure.

Table 1 below gives the indicators of the first part of the work to be analyzed. 
Table 1. Housing indicators.

\begin{tabular}{|c|c|c|}
\hline Phenomenon & Indicator & Obtaining of the Indicators \\
\hline $\begin{array}{l}\text { Evolution in the number } \\
\text { of secondary dwellings }\end{array}$ & $\%$ of secondary dwellings (2001-2011) & $\begin{array}{l}\text { [(Secondary Housing } 2011 \times 100) / \text { Total Housing 2011] } \\
-(\text { Secondary Housing } 2001 \times 100) / \text { Total Housing 2001] }\end{array}$ \\
\hline $\begin{array}{l}\text { Underutilization of the } \\
\text { housing stock }\end{array}$ & \% of empty dwellings (2001-2011) & $\begin{array}{l}\text { [(Empty housing } 2011 \times 100) / \text { Total housing 2011] }- \\
{[(\text { Empty housing } 2001 \times 100) / \text { Total housing 2001] }}\end{array}$ \\
\hline Tenancy percentage & $\begin{array}{l}\% \text { of rental housing over main housing } \\
\text { units (2001-2011) }\end{array}$ & $\begin{array}{l}\text { [(Rental housing } 2011 \times 100) / \text { Main housing 2011] - } \\
{[(\text { Rental housing } 2001 \times 100) / \text { Main housing 2001] }}\end{array}$ \\
\hline Touristification of housing & $\begin{array}{l}\% \text { of tourist accommodation as a } \\
\text { percentage of total accommodation }\end{array}$ & $\begin{array}{l}\text { (Tourist rental housing in the historic center } \times \\
100) / \text { Total housing in the historic center }\end{array}$ \\
\hline $\begin{array}{l}\text { Centralization of tourist } \\
\text { housing }\end{array}$ & $\begin{array}{l}\% \text { of tourist rentals in the municipality } \\
\text { that are located in the historic center }\end{array}$ & $\begin{array}{l}\text { (Tourist rental housing in the historic center } \times \\
\text { 100)/Total Tourist rental housing in the municipality }\end{array}$ \\
\hline Tourist Rent Gap & $\begin{array}{l}\text { Difference between the average price of } \\
\text { conventional rentals and the average } \\
\text { price of tourist accommodation }\end{array}$ & $\begin{array}{l}\text { [(Average annual rent for tourist rentals-average } \\
\text { annual rent for conventional rentals }) \times 100] / \text { average } \\
\text { annual rent for conventional rentals }\end{array}$ \\
\hline
\end{tabular}

For the socio-demographic dimension, data were obtained from the Population and Housing Census of 2001 and 2011 and from the Population Register, between 2001-2018, provided by the National Statistics Institute (INE) and the Andalusian Institute of Statistics and Cartography (IECA). The Population and Housing Census has the advantage of presenting data on socio-occupational status and educational attainment, which can be used as a proxy for the status of the population in a given urban sector.

The gentrification indicator is constructed from the variation in the percentage of the population with professional and technical occupations. The so-called Marcuse index is used [30], where the operational definition is the relative change of a socio-economic group in the area in question, minus the relative change of the same group in the city. This allows us to know whether, in a given area, a social group that is contextually considered privileged has grown at a faster or slower rate than that of the city. The transnational gentrification indicator again uses Marcuse's index, but it takes as a privileged group the foreign population from the EU-15, the US and Japan, which would reflect what is generally recognized as core countries or countries with a higher level of development. This is a rather uncontroversial choice if we are talking about the first decade of the 21st century.

Table 2 presents the socio-demographic indicators, which is the second part of the work to be analyzed.

Table 2. Socio-demographic indicators.

\begin{tabular}{ccc}
\hline Phenomenon & Indicator & Obtaining of the Indicators \\
\hline Population variation & $\begin{array}{c}\text { Population living in the historic center } \\
(2001-2018)\end{array}$ & $\begin{array}{c}\text { Resident population 2001-resident } \\
\text { population 2018 }\end{array}$ \\
\hline $\begin{array}{c}\text { Demographic percentage } \\
\text { of the historic center }\end{array}$ & $\begin{array}{c}\text { \% of population living in the historic center } \\
(2001-2018)\end{array}$ & $\begin{array}{c}\text { Resident population in the historic center } \times \\
100) / \text { Total population in the municipality }\end{array}$ \\
\hline $\begin{array}{c}\text { Ageing of the } \\
\text { historic center }\end{array}$ & \% over 65 (2001-2018) & (Older than 65 years $\times$ 100)/Total population \\
\hline $\begin{array}{c}\text { Transnationalization of } \\
\text { the central areas }\end{array}$ & $\%$ of foreigners in the historic center $(2001-2018)$ & (Total foreign population $\times$ 100)/Total population \\
\hline $\begin{array}{c}\text { Gentrification } \\
\text { Transnational } \\
\text { gentrification }\end{array}$ & $\begin{array}{c}\text { \% from countries with high HDI in the center } \\
\text { compared to increase in the city as a whole }\end{array}$ & $\begin{array}{c}\text { (Adult population with university } \\
\text { education } \times \text { 100)/Total adult population }\end{array}$ \\
\hline
\end{tabular}




\section{Results}

The results of the descriptive analysis of the housing and socio-demographic indicators are shown below. Starting with the analysis that shows the use of the housing stock in the historic centers of Seville and Cádiz, the existing concentration of tourist rentals and the difference in the income generated by tourist rentals are compared to conventional rentals. Next, the changes in the population of the historic centers are observed, studying processes of a socio-demographic nature. This will allow us to launch hypotheses, in the conclusions section, on the relationship and the differences between the two case studies.

\subsection{Tourist Housing and Rent Differential}

Table 3 represents the amount of secondary, empty, and rented dwellings and their variation between the last two population censuses.

Table 3. Percentage of secondary, empty, and rented dwellings in Seville and Cádiz and their historic centers (2001-2011). Source: Prepared by the authors with data from population and housing census 2001-2011 [31].

\begin{tabular}{cccccccccc}
\hline & \multicolumn{3}{c}{ \% Secondary Dwelling } & \multicolumn{3}{c}{ \% Empty Dwelling } & \multicolumn{3}{c}{ \% Rental Housing } \\
\hline & 2001 & 2011 & $\Delta 2001-2011$ & 2001 & 2011 & $\Delta 2001-2011$ & 2001 & 2011 & $\Delta 2001-2011$ \\
Cádiz & 6.14 & 9.03 & +2.89 & 10.36 & 11.62 & +1.25 & 31.59 & 24.85 & -6.74 \\
Cádiz HC & 3.90 & 6.80 & +2.91 & 14.76 & 19.72 & +4.96 & 54.99 & 44.90 & -10.80 \\
Seville & 7.22 & 6.11 & -1.11 & 14.71 & 14.29 & -0.42 & 10.35 & 11.81 & +1.46 \\
Seville HC & 9.09 & 9.10 & +0.01 & 29.27 & 24.37 & -4.90 & 26.52 & 27.04 & +0.52 \\
\hline
\end{tabular}

As usual in Andalusian cities, the greatest percentage of rentals in both cities is concentrated in their respective historic centers. However, the percentage of rentals is much greater in the case of the historic center of Cádiz, where it oscillates around half of the main dwellings, while in Seville it is above a quarter.

Furthermore, there is a much greater proportion of secondary and empty dwellings in the case of the historic center of Seville than in the case of Cádiz. In Seville, the intercensal period marks a certain residential dynamism, as the proportion of empty housing diminishes and secondary housing remains stagnant, while rental housing increases slightly, although less than in the city as a whole. The opposite is true in Cádiz, where renting is falling, losing up to 10 points in the historic center, and the percentage of vacant and secondary dwellings is increasing. Developments in Seville seem to correspond to demographic growth, rejuvenation, and increase of the foreign population in the first decade of the 21st century, from 7180 foreigners in the city in 2001 to 39,000 in 2013, as can be seen in the data provided by the Population Register of the National Institute of Statistics. This brings into play a greater number of dwellings, many of which are rented. In the case of Cádiz, the real estate market in this period seems to be increasingly directed to other forms of tenure, mainly ownership, and also to secondary dwellings.

We continue our work with Table 4, which analyzes the touristification of housing and centralization of tourist housing.

Table 4. Touristification of housing and centralization of tourist housing (2019). Source: Prepared by the authors with data from Datahippo.

\begin{tabular}{cccc}
\hline & $\begin{array}{c}\text { Total Number of } \\
\text { Tourist Dwellings }\end{array}$ & $\begin{array}{c}\text { Centralization of } \\
\text { Tourist Housing }\end{array}$ & $\begin{array}{c}\text { Touristification of } \\
\text { Housing }\end{array}$ \\
\hline Historic Center of Cádiz & 897 & 61.61 & 6.51 \\
Historic Center of Seville & 4840 & 65.20 & 18.24 \\
\hline
\end{tabular}

Table 4 shows that the number of tourist dwellings varies greatly between the historic center of Cádiz and that of Seville, and is much higher in the latter, reflecting its larger size in terms of surface area and population. The indicator of the centralization of this type of dwelling, which aims to reflect the proportion of the total number of tourist rentals in the 
municipality that are located in the historic center, reveals a similar figure, with over $60 \%$ of this type of housing concentrated in the historic centers, which shows the prominence of tourist housing in this type of space.

Finally, the touristification of housing shows a much higher figure in Seville, up to 18.24 points, compared to 6.51 points in the historic center of Cádiz, which implies that, in the historic center of Seville, tourist housing was approaching $20 \%$ of the total housing stock (main and other types). Through Airbnb and Idealista, we searched for an approximation of the difference in rent between the value of conventional rentals and tourist rentals. The data was calculated on an annual basis. It was calculated for dwellings with two bedrooms. Taking into account the strong seasonal variation of tourist rentals, the difference between high and low season was calculated. It should be recalled that the dates used to calculate the high season were Carnival in Cádiz and Easter in Seville. Two significant assumptions are made here. First, it is assumed that there are three months of high season in both cities. Second, it is assumed that the tourist accommodation would be rented for the whole month in the high season and half of the month in the low season.

We continue with Table 5, which shows the difference in profit a tenant would make between a conventional and a tourist rental.

Table 5. Annual rent differential in two-bedroom homes. Source: Prepared by the authors with data from Airbnb and Idealista.com.

\begin{tabular}{lcccc}
\hline & $\begin{array}{c}\text { (A) Tourist Rentals } \\
\text { Annual Average }\end{array}$ & $\begin{array}{c}\text { (B) Conventional Rentals } \\
\text { Annual Average }\end{array}$ & A-B & [(A-B) $\times$ 100/A] \\
\hline Historic Center of Seville & $€ 30,832.68$ & $€ 12,943.68$ & $€ 17,889$ & $58.02 \%$ \\
Historic Center of Cádiz & $€ 31,593.24$ & $€ 7872$ & $€ 23,721.24$ & $75.08 \%$ \\
\hline
\end{tabular}

In the center of Seville, there is a difference of $58.02 \%$ more profit for the tourist rental of a property, while in the historic center of Cádiz the difference is even greater, reaching $75.08 \%$. This difference justifies the move from conventional rentals to tourist rentals. These benefits would multiply in the months with the greatest influx of tourists. For a month during high season in Seville, the lessor would obtain $€ 5000$ more profit on average than a conventional rental. This difference, in Cádiz, amounts to more than $€ 7000$.

\subsection{Socio-Demographic Changes and Gentrification}

During the second half of the 20th century, the historic centers of the cities of Seville and Cádiz were experiencing strong population decline. They were generally losing population to other neighborhoods in their respective cities or to their metropolitan areas and were ageing markedly. Urban renewal in this type of historic centers, which is widespread in cities of a certain size in Spain, took place from the 1990s onwards [32].

The data on the historic centers of Seville and Cádiz are shown in Table 6.

In Table 6, we can see how the historic center of Cádiz has more population weight than Seville, despite the fact that Cádiz has lost inhabitants and Seville has gained them. $30.01 \%$ of the city's total population still lives in the historic center of Cádiz, while in Seville the figure is only $8.19 \%$. Beyond this, the behavior of the two historic centers is notoriously dissimilar. The historic center of Cádiz has continued to lose population by more than 6700 inhabitants for the whole period. The loss of the demographic percentage of the historic center was very rapid in the first years of the 21st century. However, these losses in favor of the city as a whole have slowed down since 2009, gaining a greater proportion between this year and 2012 only to fall again from this date onwards, albeit slightly. 
Table 6. Changes in the population of the historic centers of Cádiz and Seville. Prepared by the authors with data from the Population Register and the National Statistics Institute (INE).

\begin{tabular}{cccc}
\hline & Year & Historic Center of Seville & Historic Center of Cádiz \\
\hline \multirow{2}{*}{ Population variation } & 2001 & 52,840 & 41,819 \\
& 2018 & 56,419 & 35,111 \\
& $\Delta 2001-2018$ & +3579 & -6708 \\
\hline \% Demographic percentage of the & 2001 & 7.52 & 31.36 \\
historic center & 2018 & 8.19 & 30.01 \\
& $\Delta 2001-2018$ & +0.67 & -1.35 \\
\hline \% Ageing & 2001 & 20.37 & 36.25 \\
& 2018 & 20.19 & 28.38 \\
& $\Delta 2001-2018$ & -0.18 & -7.87 \\
& 2001 & 1.96 & 0.55 \\
\end{tabular}

In this process, the ageing of the population decreased notably, from $36 \%$ to $28 \%$ of the population, and was also accompanied by an increase in the transnationalisation of the historic center, albeit a very moderate one. In Seville, on the other hand, the demographic percentage of the population of the historic center has increased in the period 2001-2018, though only slightly. The population percentage increased notably in the first decade of the 21st century and until 2012, after which it began to decrease in share in the city as a whole. The total number of residents in the historic center of Seville has been increasing significantly, year after year, since the beginning of the 21st century, reaching more than 60,000 residents. This trend has slowed and reversed since 2013, and in this time the number of residents has fallen by 3653 , erasing much of the previous growth. During this period, the ageing of the population hardly changed in Seville and there was a greater transnationalization than in the case of Cádiz, although the percentage of foreigners barely surpassed $6 \%$ of the population. In Cádiz, ageing has declined more or less constantly; in Seville, while the demographic percentage of the center grew, it also grew younger, but since 2013, when this growth slowed down, it has been ageing again year by year.

On the other hand, it is noticeable how the increase in the proportion of foreigners has been constant from year to year, but has started to decrease in both cities, precisely from 2013 onwards, coinciding in both cases with the halt of previous trends of population increase in Seville or the halting of the demographic decline in Cádiz.

In short, in the case of Seville, there is a clear change in demographic trends, with a turning point in 2012, which is much more subdued in the historic center of Cádiz. In the period prior to 2013, there was a growth in the population, accompanied by an increase in the percentage of the foreign population and a rejuvenation of the population, which implies some kind of replacement of the older population with the entry of new settlers, young people and with a certain proportion of foreign population. The case of Cádiz is similar, but this process only allowed for a certain slowdown of the population decline between 2005 and 2012. The subsequent population decline from 2013 onwards in the historic center of Seville implies a loss of the foreign population and a new ageing, which indicates that the population lost in this period is a young population that includes foreigners. This last point can also be extended to the historic center of Cádiz, although in this case the ageing process did not stop during the entire series of data.

The following table shows the indicators of gentrification and transnational gentrification in the historic center of Seville and Cádiz.

In Table 7, the gentrification rates show a positive variation during the study period for both cases, although the increase is rather mild. The general gentrification rate is higher in the historic center of Cádiz, above $4 \%$, coinciding with an increase of one point in the percentage of professionals and technicians over the total population of working age. 
Table 7. Gentrification and transnational gentrification. Source: Prepared by the authors with data from population and housing census 2001-2011, the Population Register and the National Statistics Institute (INE).

\begin{tabular}{|c|c|c|c|c|c|}
\hline & $\begin{array}{l}\text { Gentrification } \\
\text { Rate 2001-2011 }\end{array}$ & $\begin{array}{r}\text { \% Profe } \\
\text { Technicia }\end{array}$ & $\begin{array}{l}\text { ls and } \\
01-2011\end{array}$ & $\begin{array}{c}\text { Transnational } \\
\text { Gentrification Rate } \\
\text { 2001-2018 }\end{array}$ & $\begin{array}{c}\text { Foreigners EU-15, USA, } \\
\text { Canada and Japan } \\
\Delta 2001-2018\end{array}$ \\
\hline $\begin{array}{l}\text { Historic Center of } \\
\text { Cádiz }\end{array}$ & 4.15 & $\begin{array}{l}21.23 \% \\
22.31 \%\end{array}$ & +1.08 & 0.38 & +0.73 \\
\hline $\begin{array}{l}\text { Historic Center of } \\
\text { Seville }\end{array}$ & 1.91 & $\begin{array}{l}51.42 \% \\
52.06 \%\end{array}$ & +0.67 & 1.60 & +1.97 \\
\hline
\end{tabular}

In the case of Seville's historic center, the index is slightly below $2 \%$, reflecting a smaller increase in this group. It should be noted that, for this period, the historic center of Seville is characterized as a very privileged sector compared to that of Cádiz, with more than half of the population employed in professional trades-a percentage that is less than a quarter in the case of Cádiz. Leaving aside the issue of the great internal diversity that exists in both historic centers, this could point to an earlier process of gentrification in the case of Seville, as the available literature indicates [33]. In the case of transnational gentrification, the opposite seems to be the case. It also has positive values. However, transnational gentrification this time is much higher in the case of the historic center of Seville, where it is $1.6 \%$, corresponding to a notable increase in the percentage of foreigners from the most developed countries. In Cádiz, the figure is much lower and remains at $0.38 \%$.

The data in Table 7 add a certain nuance to the previous observations on population change in the two historic centers under study. The population that has promoted growth and rejuvenation during certain periods has been a socially privileged population, which would imply a degree of gentrification of the sector that is more noticeable during the study period in Cádiz, and even a degree of transnational gentrification that would be more significant in Seville.

\section{Conclusions}

The high number of tourist dwellings and the difference in income between tourist housing and conventional rentals could be the main variable explaining the population losses in these historic centers in recent years. The impact of the growth of this type of tourist accommodation since 2012 is directly related to population losses, especially in Seville, thus reversing previous trends. On a statistical level, there is a relationship between socio-demographic and housing use structures and the distribution of tourist rentals, with the most explanatory variables being proximity to the center, housing uses and the presence of foreign population from countries with a high socio-economic level.

It has been possible to demonstrate that since 2013 there has been a loss of population in the historic centers of both cities that coincides with a clear irruption of digital tourist rental platforms, as already proposed by other authors such as Postma and Schmuecker, [5] and Veiga et al. [4], giving strength to the hypothesis that the high number of tourist homes and the difference in rent may be a reason for the process of touristification, as already indicated by Wachsmuth and Weisler [20].

At the same time, the high level of housing touristification in Seville coincides with a certain degree of transnational gentrification, which initially seems to be a logical relationship between the presence of foreign residents from wealthy countries and the supply of temporary accommodation for visitors from these same countries. In Seville, the phenomenon of touristification as the substitution of residents for visitors is clearer, but Cádiz has certain elements that make it more vulnerable. This is mainly due to the fact that its historic center is home to a population of lower status and with a greater share of tenants, which reduces its capacity to compete for residential space in the area and increases the risk of involuntary displacement. 
The hypothesis of a link between touristification and population loss is strengthened by this work. However, in order to infer a cause-effect relationship between the increase in temporary tourist apartments and population losses, it would be necessary to have time series data on the former and to apply some kind of linear regression at a high level of disaggregation within historic centers, which could be a future line of work.

The relationship between gentrification and touristification is also a complex issue. From the outset, there seems to be a certain correlation between transnational gentrification and touristification. Nevertheless, in general terms, gentrification associated with the rejuvenation of historic city centers seems to precede and may even be negatively affected by the loss of residents, which affects young households as well as foreign households. Regarding whether or not this type of process is beneficial, although the main virtue of gentrification may have been the rejuvenation and reversal of the demographic decline of historic centers, the intensification of these dynamics related to touristification may be undermining these small gains. This is a point that needs to be further elaborated upon in the future development of this research.

Author Contributions: Conceptualization, formal analysis, investigation, methodology, writingoriginal graft, writing - review \& editing, J.-J.P.; Conceptualization, formal analysis, investigation, methodology, supervision, I.D.-P. All authors have read and agreed to the published version of the manuscript.

Funding: This research received no external funding.

Institutional Review Board Statement: Not applicable. The study does not include humans or animals.

Informed Consent Statement: Not applicable.

Conflicts of Interest: The authors declare no conflict of interest.

\section{References}

1. Marchena Gómez, M.; Vera Rebollo, J.F. Turismo y Desarrollo: Un planteamiento actual. Pap. Turisme 1990, 3, 59-84. Available online: https:/ /idus.us.es / xmlui/ bitstream/handle/11441/47549/turismoydesarrollounplanteamientoactual.pdf?sequence=1 (accessed on 26 March 2019).

2. Peeters, P.; Gössling, S.; Klijs, J.; Milano, C.; Novelli, M.; Dijkmans, C.; Eijgelaar, E.; Hartman, S.; Heslinga, J.; Isaac, R.; et al. Research for TRAN Committee-Overtourism: Impact and Possible Policy Responses. October 2018. Available online: https: //www.europarl.europa.eu/RegData/etudes/STUD/2018/629184/IPOL_STU(2018)629184_EN.pdf (accessed on 10 April 2019).

3. Capocchi, A.; Vallone, C.; Pierotti, M.; Amaduzzi, A. Overtourism: A Literature Review to Assess Implications and Future Perspectives. Sustainability 2019, 11, 3303. [CrossRef]

4. Veiga, C.; Santos, M.C.; Âguas, P.; Santos, J.A.C. Sustainability as a key driver to address challenges. Worldw. Hospitality. Tour. Themes. 2018, 10, 662-673. [CrossRef]

5. Postma, A.; Schmuecker, D. Understanding and overcoming negative impacts of tourism in city destinations: Conceptual model and strategic framework. J. Tour. Futures 2017, 3, 144-156. [CrossRef]

6. Chamorro, R. Una revolución en el turismo gracias a las TIC. Rev. Bit. 2008, 170, 30-33.

7. Cuadrado Roura, J.R.; Lopez Morales, J.M. El Turismo en la Recuperación y el Equilibrio Exterior de España. Papeles de Economia Espanñola 2018, 154-171. Available online: https:/ / dialnet.unirioja.es/servlet/articulo?codigo=6752653 (accessed on 12 April 2019).

8. Cócola Gant, A.; Durán, G.; Janoschka, M. La ciudad del siglo XXI: Políticas públicas urbanas, desplazamientos y contestaciones. Íconos-Revista de Ciencias Sociales 2016, 11. [CrossRef]

9. Gil, J.; Sequera, J. Expansión de la ciudad turística y nuevas resistencias: El caso de Airbnb en Madrid. Rev. Metodol. Cienc. Sociales. 2018, 15-32. [CrossRef]

10. Ortuño, A.; Jiménez, J.L. Economía de plataformas y turismo en España a través de Airbnb. Cuad. Económicos de ICE 2019, 133-153. [CrossRef]

11. Milano, C. Overtourism, malestar social y turismofobia. Un debate controvertido. PASOS Rev. Turismo y Patrimonio Cult. 2018, 18, 551-564. [CrossRef]

12. Gotham, K.F. Tourism gentrification: The case of New Orleans' vieux carre (french quarter). Urban Stud. 2005, 42, 145-176. [CrossRef]

13. Cocola gant, A. Gentrificación y desplazamiento: Desigualdad urbana en ciudades del capitalismo tardío. Man. Geogr. Urbana 2019, 297-310. [CrossRef]

14. Füller, H.; Michel, B. “Stop Being a Tourist!” New Dynamics of Urban Tourism in Berlin-Kreuzberg. Int. J. Urban Reg. Res. 2014, 38, 1304-1318. [CrossRef] 
15. Jover, J.; Díaz-Parra, I. Gentrification, transnational gentrification and touristification in Seville, Spain. Urban Stud. 2019, 1-16. [CrossRef]

16. Clark, E. The order and simplicity of gentrification: A political challenge. Gentrification Read. 2004, 24-29. [CrossRef]

17. Smith, N. La nueva frontera urbana. Ciudad revanchista y gentrificación. Trans. Inst. Br. Geogr. 1996, 20, 236-247. Available online: https:/ / www.traficantes.net/sites/default/files/pdfs/Lanuevafronteraurbana-TdS.pdf. (accessed on 14 March 2019).

18. Cócola Gant, A. Boletin sobre el turismo reponsable. Tursimo y Desarro. 2015, 15, 12.

19. Horna, K.; Merantea, M. Is home Sharing Driving Up Rents? Evidence from Airbnb in Boston. J. Hous. Econ. 2017, 38, 14-24. [CrossRef]

20. Wachsmuth, D.; Weisler, A. Airbnb and the rent gap: Gentrification through the sharing economy. Environ. Plan. A 2018, 50, 1147-1170. [CrossRef]

21. Andalusian Institute of Statistics and Cartography (IECA). Spatial Reference Data of Andalusia (DERA). Available online: www.juntadeandalucia.es/institutodeestadisticaycartografia (accessed on 14 February 2020).

22. National Statistical Institute (INE). Population Register. Available online: www.INE.es (accessed on 18 March 2019).

23. Airbnb. Accommodation. Available online: www.airbnb.es (accessed on 10 February 2019 and 30 February 2019).

24. DataHippo. Tourist dwellings. Available online: https:// datahippo.org/es/ (accessed on 10 January 2019).

25. de Andalucía, J. BOJA Decreto 28/2016, de 2 de febrero, de las viviendas con fines turísticos y de modificación del Decreto 194/2010, de 20 de abril, de establecimientos de apartamentos turísticos, de 2 de febrero. Núm.28 página 66. 2016. Available online: https: / /www.juntadeandalucia.es/boja/2016/28/6 (accessed on 20 December 2018).

26. Idealista. Rental Housing. Available online: www.idealista.com (accessed on 10 February 2019).

27. Miles, M. Encuesta de ocupación hotelera (EOH). Available online: www.ine.es/jaxiT3/Tabla.htm?t=2078) (accessed on 29 March 2019).

28. Hotel Association of Seville and Province. Hotel Occupancy. Available online: www.hotelesdesevilla.com (accessed on 15 May 2019).

29. Federation of hotel and catering businessmen of the province of Cadiz (HORECA). Hotel Occupancy. Available online: www. horecacadiz.org (accessed on 15 May 2019).

30. Rasse, A.; Sabatini, F.; Sarella-Robles, M.; Gomez-Maturano, R.; Cáceres, G.; Trebilcock, M.P. Metodologías de identificación de zonas en gentrificación. Santiago de Chile y Ciudad de México. Rev. Bitácora Urbano Territ. 2019. [CrossRef]

31. National Statistical Institute (INE). Population and Housing Census 2001-2011. Available online: https://www.ine.es/dyngs/ INEbase/es/operacion.htm?c=Estadistica_C\&cid=1254736176992\&menu=resultados\&idp=1254735572981 (accessed on 25 March 2019).

32. Díaz Parra, I. Cambios en la geografía social de Sevilla 1981-2001. Cuad. Geogr. 2010, 46, 139-161.

33. Parra, I.D. Gentrificación o Barbarie? Disciplinamiento y Transformación Social de Barrio de la Alameda de Sevilla 2014. Available online: https://www.academia.edu/7908159/_Gentrificación_o_barbarie_Disciplinamiento_y_transformación_social_ de_barrio_de_la_Alameda_de_Sevilla (accessed on 13 March 2019). 